\title{
Impact of migration on tuberculosis epidemiology and control in the EU/EEA
}

MJ van der Werf ${ }^{1}$, JP Zellweger ${ }^{2}$

1. European Centre for Disease Prevention and Control (ECDC), Stockholm, Sweden

2. Swiss Lung Association, Berne, Switzerland

Correspondence: Marieke J. van der Werf (marieke.vanderwerf@ecdc.europa.eu)

Citation style for this article:

van der Werf MJ, Zellweger JP. Impact of migration on tuberculosis epidemiology and control in the EU/EEA. Euro Surveill. 2016;21(12):pii=30174. DOI: http://dx.doi. org/10.2807/1560-7917.ES.2016.21.12.30174

Article submitted on 10 March 2016 / accepted on 23 March 2016 / published on 24 March 2016

Recently, European Union (EU)/European Economic Area (EEA) countries have witnessed an unprecedented volume of migration, with 1,046,599 migrants arriving in Europe in 2015 [1]. Of these migrants, most have Syrian, Afghan or Iraqi nationality, and they mainly arrived via the eastern Mediterranean route. Before the increase in migration in 2015, the EU/EEA area was already an attractive destination, with 33.5 million people born outside of the EU living in an EU country on 1 January 2014 [2].

Two reports published in this issue of Eurosurveillance address the potential impact of migration on tuberculosis (TB) epidemiology in the EU/EEA [3,4]. The article by Hollo et al. [3] focuses on the influence of migratory movements within the EU/EEA of people originating from other EU/EEA countries. Within the EU, free movement of persons is a fundamental right which is guaranteed to EU citizens by the Treaties [5]. In 2013, 3.3\% of all TB cases notified in the EU/EEA originated from other EU/EEA countries and more than $60 \%$ of those originated from Poland and Romania. This reflects the diversity of the epidemiological settings and migration flows within the EU/EEA, with Romania having a high TB notification rate whereas the TB notification rate in Poland is only slightly above the EU/EEA average [6]. The article addresses the possible impact of this diversity on the local incidence of disease. Ködmön et al. [4] analysed the epidemiology of TB cases in individuals originating from outside the EU/EEA. In 2013, these accounted for $22 \%$ of all notified TB cases. The difference in incidence between the migrants' country of origin and country of settlement may be greater than the differences between EU/EEA countries, and the potential impact is a matter of concern.

The latest TB surveillance data report, published by the World Health Organization Regional Office for Europe and the European Centre for Disease Prevention and Control on the occasion of World TB Day 2016, shows that in $2014,58,008$ TB cases were reported by $29 \mathrm{EU} /$ EEA countries (Italy and Liechtenstein did not report), a notification rate of 12.8 TB cases per 100,000 population [6]. Since the start of EU-level TB surveillance in 1995, the annual number of reported cases has decreased by almost $50 \%$ [7], with a decrease in the TB notification rate of on average $3.8 \%$ per year in the last five years. There is significant heterogeneity in the EU/EEA, with country-specific notification rates differing more than 30 -fold, ranging from 2.5 in Iceland to 79.7 per 100,000 in Romania, and with 18 countries reporting rates below 10 cases per 100,000. Likewise, the case load is unevenly distributed with three countries (Poland, Romania and the United Kingdom (UK)) accounting for ca $50 \%$ of all reported cases and Romania alone accounting for $27 \%$ of all cases.

Of all TB cases notified in 2014, 15,565 (27\%) were diagnosed in individuals of foreign origin, i.e. is born in a country different to the reporting country [6]. The proportion of TB cases in individuals of foreign origin increased in the last decade from $20 \%$ in 2005 to $27 \%$ in 2014. This proportional increase does not reflect an increase in numbers. Country-specific proportions of TB cases in individuals of foreign origin ranged from below $1 \%$ in Bulgaria, Poland and Romania to above $75 \%$ in Cyprus, Iceland, Luxembourg, Malta, Norway and Sweden (Figure).

Four countries (France, Germany, Spain and the UK) reported $75 \%$ of all cases in individuals of foreign origin. Thus, for the EU/EEA to progress towards TB elimination, we need to address TB in migrant population groups [8].

The TB notification data of 2015 are currently being collected by the countries and will be notified to the EU-level surveillance system later this year. EU-level TB surveillance data allow for evaluating total number of TB cases in individuals from other countries but not 
Percentage of tuberculosis cases in individuals of foreign origin, European Union/European Economic Area, 2014 $(\mathrm{n}=58,008)$

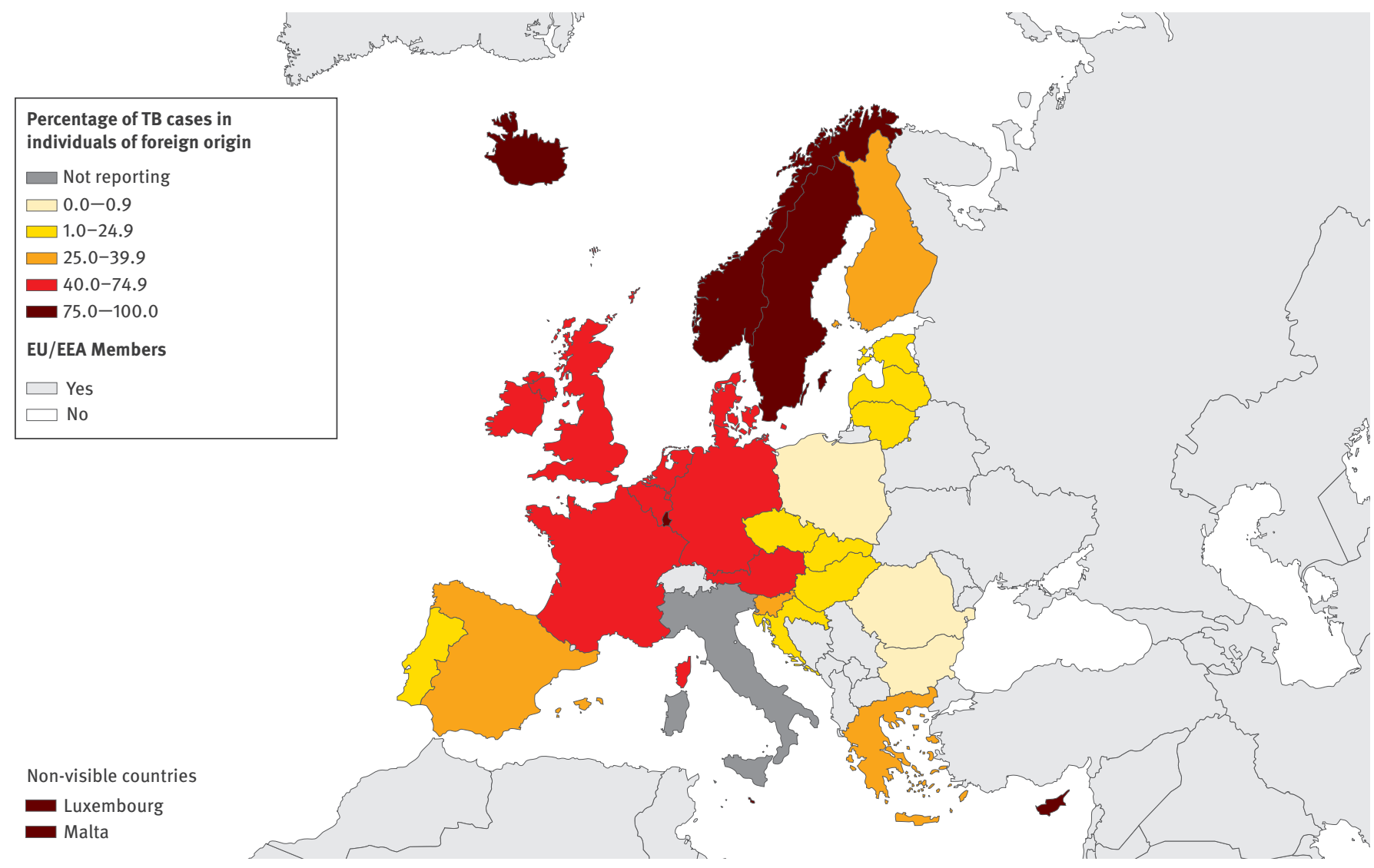

EU/EEA: European Union/European Economic Area; TB: tuberculosis.

Source: [6]

for assessing the influence of recent migration on TB epidemiology since information on time since arrival in the country is not requested. This information is collected in a number of EU/EEA countries, for example in UK and the Netherlands $[9,10]$.

Historically, migrants have frequently been regarded as potential carriers of disease that could be transmitted to the local population or generate costs to the health system. This was already the case when Europeans migrated to America in the 19th century and were submitted to stringent health controls before departure and on arrival, mainly for the identification of TB and psychiatric diseases, thus ascertaining that they would not be a financial burden for the society [11]. Hollo et al. [3] showed that only a small proportion of TB cases in individuals of foreign origin in EU/EEA countries originated from other EU/EEA countries and therefore transmission associated with migration within the EU/ EEA will be limited. While the report by Ködmön et al. [4] acknowledges the important and increasing contribution of migration from high-incidence countries outside the EU/EEA to the epidemiology of TB in Europe, the risk of TB transmission to the resident population appears to be negligible based on the results of studies using genotyping information $[12,13]$.

Screening migrants, before, at or after entry, may be considered and is an option that is implemented by some EU countries [14]. It aims at identifying active TB cases before or soon after arrival in the host country to ensure treatment and to limit onward transmission. The timing, extent and procedure of screening applied in the different EU/EEA countries are very diverse [14] and information on cost effectiveness is limited [15]. What has been shown is that TB rates often remain high in migrant populations long after entry into the host country due to reactivation of a previously acquired TB infection or, more rarely, recent infection acquired in the receiving country $[16,17]$. Therefore, some countries submit migrants to repeated screening [18]. In general, this implies higher costs, and the yield of repeated screening seems to decrease with time.

It is important to remember that, even in population groups where TB is considered a frequent disease, the incidence rate is seldom higher than 200 per 100,000 population, meaning that the vast majority of migrants, 
even those originating from so-called high-incidence countries do not have and never will develop TB. Targeting the appropriate group and using the appropriate method for screening is therefore important and can reduce the cost of the procedure.

The estimated TB incidence in two of the three main countries of origin of the current migrants (Afghanistan, Iraq and Syria) is not substantially different from that in the EU/EEA, i.e. 189 per 100,000 population in Afghanistan, 43 in Iraq and 17 in Syria vs 13.2 per 100,000 in the EU/EEA (range: 3.3 in Iceland to 81.0 in Romania) [19]. As expected, the number of TB cases detected when screening Syrians is low [20]. Thus, screening for active TB is presumably not a good option for migrants from low TB incidence countries. Nevertheless, migrants may have an increased risk of acquiring TB infection or developing TB disease due to the challenging conditions encountered during travel to the EU/EEA or while waiting in the reception centres or temporary housing for the result of their application for refugee status. A pilot study conducted in Switzerland demonstrated that migrants who travelled by ground and sea transportation had a significantly higher risk of having latent TB infection (LTBI) than migrants travelling by air [21]. Thus travel and housing conditions should be taken into account when assessing whether screening programmes are necessary.

To reduce the pool of $T B$-infected cases that might give rise to active TB cases, migrants can be screened for LTBI by tuberculin skin test or interferon gamma release assay. This strategy has been implemented in some countries for all legal migrants, for selected categories of legal migrants or for asylum seekers/refugees [14]. Screening for LTBI and providing preventive treatment has been shown to be cost-effective for migrants from countries with a TB incidence of more than 200 per 100,000 , especially if the strategy is focused on young migrants [22].

In conclusion, even though the majority of migrants entering the $\mathrm{EU}$ at the moment do not originate from high-incidence countries, TB in migrants is proportionally becoming more important in the EU/EEA. Migrants may arrive in the EU/EEA with TB or develop TB later on due to a latent infection contracted in their country of origin. Screening for active disease (by radiography or clinical examination) can diagnose prevalent TB but will not reduce incident TB after arrival. Thus, it is crucial to make the health system accessible to all, including undocumented migrants, and to provide migrants with the care that they need to ensure early TB diagnosis and treatment [23].

\section{Conflict of interest}

MvdW is among the authors of references [3] and [4] described in this editorial.
Authors' contributions

MvdW and JPZ contributed equally to the writing of the manuscript.

\section{References}

1. International Organization for Migration (IOM). Migration flows - Europe. Geneva: IOM. [Accessed Feb 2016]. Available from: http://migration.iom.int/europe/.

2. Eurostat. Europe in figures - Eurostat yearbook. Luxembourg: Eurostat. [Accessed Feb 2016]. Available from: http:// ec.europa.eu/eurostat/statistics-explained/index.php/ Europe_in_figures_-_Eurostat_yearbook.

3. Hollo V, Kotila SM, Ködmön C, Zucs P, van der Werf MJ. The effect of migration within the European Union/European Economic Area on the distribution of tuberculosis, 2007 to 2013. Euro Surveill. 2016;21(12): pii=30171. DOI: $10.2807 / 1560$ 7917.ES.2016.21.12.30171

4. Ködmön C, Zucs P, van der Werf MJ. Migration-related tuberculosis: epidemiology and characteristics of tuberculosis cases originating outside the European Union and European Economic Area, 2007 to 2013.Euro Surveill. 2016;21(12): $\mathrm{pil}=30164$. DOI: $10.2807 / 1560-7917$. ES.2016.21.12.30164

5. Consolidated version of the Treaty on the Functioning of the European Union Official Journal. Official Journal of the European Union. Luxembourg: Publications Office of the European Union; 2012. C 326;55:1-390. Available from: http://eur-lex.europa.eu/legal-content/EN/TXT/ PDF/? uri=CELEX:12012E/TXT\&from $=$ EN

6. European Centre for Disease Prevention and Control, WHO Regional Office for Europe. ECDC/WHO EURO. Tuberculosis surveillance and monitoring in Europe, 2016. Stockholm: ECDC. 2016. http://ecdc.europa.eu/ en/publications/_layouts/forms/Publication_DispForm. aspx? List $=4$ f 55 ad $51-4$ aed-4d32-b960-af70113dbb9o\&ID =1452

7. European Centre for Disease Prevention and Control (ECDC). Surveillance atlas of infectious diseases. Stockholm: ECDC. [Accessed Feb 2016]. Available from: http://ecdc.europa.eu/en/ data-tools/atlas/Pages/atlas.aspx.

8. Lönnroth K, Migliori GB, Abubakar I, D’Ambrosio L, de Vries G, Diel R, et al. Towards tuberculosis elimination: an action framework for low-incidence countries. Eur Respir J. 2015;45(4):928-52. DOI: 10.1183/09031936.00214014 PMID: 25792630

9. Public Health England (PHE). Tuberculosis in the UK, 2014 report. London: PHE; 2014. Available from: https://www.gov. uk/government/uploads/system/uploads/attachment_data/ file/360335/TB_Annual_report_4_0_300914.pdf

10. Slump E, Erkens CGM, van Hunen R, Schimmel HJ, van Soolingen D, Teirlinck AC, et al. Tuberculose in Nederland 2014. [Tuberculosis in the Netherlands 2014]. Bilthoven: Rijksinstituut voor Volksgezondheid en Milieu; 2015. Dutch. Available from: http://www.rivm.nl/dsresource?objectid=rivmp :299849\&type=org\&disposition=inline\&ns_nc=1

11. Dara M, Gushulak BD, Posey DL, Zellweger JP, Migliori GB. The history and evolution of immigration medical screening for tuberculosis. Expert Rev Anti Infect Ther. 2013;11(2):137-46. DOI: 10.1586/eri.12.168 PMID: 23409820

12. Sandgren A, Schepisi MS, Sotgiu G, Huitric E, Migliori GB, Manissero D, et al. Tuberculosis transmission between foreign- and native-born populations in the EU/EEA: a systematic review. Eur Respir J. 2014;43(4):1159-71. DOI: 10.1183/09031936.00117213 PMID: 24114966

13. Kamper-Jørgensen Z, Andersen AB, Kok-Jensen A, KamperJørgensen M, Bygbjerg IC, Andersen PH, et al. Migrant tuberculosis: the extent of transmission in a low burden country. BMC Infect Dis. 2012;12(1):60. DOI: 10.1186/14712334-12-60 PMID: 22423983

14. Pareek M, Baussano I, Abubakar I, Dye C, Lalvani A. Evaluation of immigrant tuberculosis screening in industrialized countries.Emerg Infect Dis. 2012;18(9):1422-9. DOI: 10.3201/ eid1809.120128 PMID: 22931959

15. Dasgupta K, Schwartzman K, Marchand R, Tennenbaum TN, Brassard P, Menzies D. Comparison of cost-effectiveness of tuberculosis screening of close contacts and foreign-born populations.Am J Respir Crit Care Med. 2000;162(6):2079-86. DOI: 10.1164/ajrccm.162.6.2001111 PMID: 11112118

16. Farah MG, Meyer HE, Selmer R, Heldal E, Bjune G. Longterm risk of tuberculosis among immigrants in Norway.Int J Epidemiol. 2005;34(5):1005-11. DOI: 10.1093/ije/dyio58 PMID. 15802379 
17. McPherson ME, Kelly H, Patel MS, Leslie D. Persistent risk of tuberculosis in migrants a decade after arrival in Australia.Med J Aust. 2008;188(9):528-31.PMID: 18459925

18. Erkens C, Slump E, Kamphorst M, Keizer S, van Gerven PJ, Bwire R, et al. Coverage and yield of entry and follow-up screening for tuberculosis among new immigrants. Eur Respir J. 2008;32(1):153-61. DOI: 10.1183/09031936.00137907 PMID: 18287123

19. World Health Organization (WHO). Global tuberculosis report 2015. Geneva: WHO; 2015. Available from: http://apps.who.int/ iris/bitstream/10665/191102/1/9789241565059_eng.pdf?ua=1

20. de Vries G, van Rest J, Meijer W, Wolters B, van Hest R. Low yield of screening asylum seekers from countries with a tuberculosis incidence of $<50$ per 100000 population. Eur Respir J. 2016;ERJ-00099-2016. DOI: 10.1183/13993003.00099-2016 PMID: 26965289

21. Sarivalasis A, Zellweger JP, Faouzi M, Daher O, Deslarzes C, Bodenmann P. Factors associated with latent tuberculosis among asylum seekers in Switzerland: a cross-sectional study in Vaud County. BMC Infect Dis. 2012;12(1):285. DOI: 10.1186/1471-2334-12-285 PMID: 23121680

22. Zammarchi L, Casadei G, Strohmeyer M, Bartalesi F, Liendo C, Matteelli A, et al. A scoping review of cost-effectiveness of screening and treatment for latent tubercolosis infection in migrants from high-incidence countries. BMC Health Serv Res. 2015;15(1):412. DOI: 10.1186/S12913-015-1045-3 PMID: 26399233

23. Dara M, de Colombani P, Petrova-Benedict R, Centis R, Zellweger JP, Sandgren A, et al. Minimum package for crossborder TB control and care in the WHO European region: a Wolfheze consensus statement. Eur Respir J. 2012;40(5):108190. DOI: 10.1183/09031936.00053012 PMID: 22653772

\section{License and copyright}

This is an open-access article distributed under the terms of the Creative Commons Attribution (CC BY 4.0) Licence. You may share and adapt the material, but must give appropriate credit to the source, provide a link to the licence, and indicate if changes were made.

This article is copyright of the authors, 2016. 